Debate sobre o artigo de Fernando Zegers-Hochschild Debate on the paper by Fernando Zegers-Hochschild

\section{Aníbal Faúndes}

Departamento de Obstetrícia e Ginecologia, Universidade Estadual de Campinas, Campinas, Brasil.
Não é fácil comentar o artigo do Dr. Zegers, por várias razões. Primeiro, porque o tema é tão recente, que não há experiência que permita sustentar uma opinião bem fundamentada. Segundo, porque o Dr. Zegers não só revela seu profundo conhecimento da biologia do desenvolvimento embrionário, como também mostra ter passado por um longo processo filosófico de meditação e análise sobre o assunto. Assim, é difícil que o comentarista se sinta autorizado para qualquer contestação. Terceiro, porque o estilo do artigo é descritivo, fazendo com que os conhecimentos atuais e as novas situações que derivam dos progressos na reprodução assistida sejam muito claramente colocados, mas sem pronunciar-se quanto à valorização das condutas alternativas que poderiam ser tomadas em cada caso.

Esta, que poderia ser a principal crítica ao trabalho, é o elemento fundamental em que o discurso do Dr. Zegers se baseia, isto é, que o conhecimento é libertador à medida que nos oferece mais elementos para fazermos nosso próprio julgamento interior e tomarmos nossas próprias decisões.

$\mathrm{O}$ artigo deixa, entretanto, alguns vazios sobre os quais o autor não se pronuncia. Zegers refere que "o número de concepti criopreservados aumenta em quantidades alarmantes...", mas não propõe alternativas de solução para esse problema. Basta lembrar que, no Reino Unido, tomou-se recentemente a decisão de autorizar que concepti criopreservados e 'abandonados' pelos seus progenitores fossem refugados, o que provocou uma enorme polêmica. É evidente que existe um limite na capacidade que os laboratórios têm de acumular concepti criopreservados. A implicação prática desta realidade é que uma proporção desconhecida, mas não desprezível, desses concepti está condenada a não sobreviver desde o momento de sua criação no laboratório.

Na introdução, Zegers deixa implícito que esses concepti não são ainda indivíduos ou pessoas, uma vez que possuem apenas de duas a quatro células, e somente quando cada um deles já não puder mais se dividir em gêmeos é que passa a ter um caráter único em matéria e espírito. Poderíamos concluir, portanto, que seria moralmente permitido, mesmo sob uma perspectiva católica, que esses concepti fossem refugados?

Em determinados momentos de sua exposição parece que o pensamento de Zegers seria contrário a essa posição, quando discute os riscos de demarcar os inícios (curiosamente no plural) de uma pessoa. Mas se o conceptus ainda não possui espírito (se o possuísse não se saberia para onde ir ao transformar-se a matéria em dois gêmeos) e não se pode considerar ainda como um indivíduo, qual seria o motivo de ter um valor maior que o espermatozóide que o gerou? Só porque já uniu-se a um oócito, apesar de não ter ainda caráter individual? Cada espermatozóide tem o potencial de dar origem a um (ou mais) indivíduos com características genéticas únicas. Uma vez refugado esse espermatozóide, nunca mais haverá a possibilidade de existir um ser humano com as características daquele que seria gerado dele.

Voltando ao esplêndido texto de Zegers, ele diz: "Cada vez que se deseja demarcar os inícios de uma pessoa, utiliza-se um juizo de valor que leva implícito que a etapa prévia ao suposto início é menos importante ou tem menos transcendência que a etapa seguinte". Essa é uma realidade incontestável. Daí a dificuldade em discutir "os inícios de uma pessoa" e de impor uma definição que todos tenham que aceitar. Este é precisamente o cerne do excelente artigo que comentamos.

Vida, para mim, é um contínuo, em que o material genético vai passando de uma geração a outra através dos gametas, concepti, embriões, fetos e indivíduos já nascidos. Apesar dos riscos colocados por Zegers, que temos que aceitar e frente aos quais temos que permanecer alertas, é impossível dar o mesmo valor a cada uma dessas etapas da seqüência que permite a continuidade da espécie humana.

Só à consciência esclarecida de cada um de nós cabe decidir onde colocamos o nosso limite. Por outra parte, a sociedade organizada tem que encontrar formas de coibir possíveis abusos. Enquanto é verdade que o médico precisa de formas de controle social, as normas que lhe são impostas não podem estar ligadas a determinada fé, mas baseadas no conhecimento e no humanismo, aos quais Zegers faz uma importantíssima contribuição com seu trabalho. 